\title{
ENTREVISTA COM A PROFESSORA DOUTORA MARIA ADÉLIA APARECIDA DE SOUZA - PARTE II
}

Gil Carlos Silveira Porto ${ }^{1}$ Márcio Abondanza Vitiello²

Resumo: Entre os dias 10 e 12 de junho de 2019, o curso de Geografia da Universidade Federal de Alfenas (UNIFAL/MG) recebeu o V GEOSIMPÓSIO e o III GEOTRANS para discutir conflitos e desigualdades territoriais na sociedade contemporânea. Foram três dias de robustos debates, que tiveram como centralidade a dimensão política do espaço geográfico e a participação de importantes intelectuais da Geografia brasileira, como a professora Maria Adélia de Souza, que na conferência de encerramento nos presenteou com a necessária discussão sobre "Desigualdades socioespaciais e a constituição dos lugares nas cidades". Na manhã do último dia do evento a professora Maria Adélia de Souza concedeu a presente entrevista, na qual retrata sua trajetória na Geografia brasileira, discorre sobre a crise que essa área do conhecimento enfrenta e reforça a importância da Geografia Nova construída pelo professor Milton Santos como possibilidade de superá-la.

Palavras-chave: Milton Santos. Lugar. Epistemologia. Totalidade. Metáfora.

\section{INTERVIEW WITH PROFESSOR MARIA ADÉLIA APARECIDA DE SOUZA, PhD - PART II}

Abstract: From June 10th to 12th, 2019, the Geography course of the Federal University of Alfenas - UNIFAL / MG received the V GEOSIMPÓSIO and III GEOTRANS to discuss conflicts and territorial inequalities in contemporary society. There were three days of robust debates, focused on the political dimension of the geographical space and the participation of important intellectuals from Brazilian Geography, such as teacher Maria Adélia de Souza, who presented the closing conference with the necessary discussion on "Socio-spatial inequalities and the constitution of places in cities". On the morning of the last day of the event, Maria Adélia gave the following interview, in which she portrays her trajectory in Brazilian Geography, discusses the crisis that this area of knowledge faces and reinforces the importance of the New Geography built by Professor Milton Santos as possibility of overcoming it.

Keywords: Milton Santos. Place. Epistemology. Totality. Metaphor.

\footnotetext{
1 Universidade Federal de Alfenas (Unifal-MG), Instituto de Ciências da Natureza, Curso de Graduação e Pós-Graduação em Geografia, Alfenas, Brasil, gil.porto@unifal-mg.edu.br, https://orcid.org/0000-0002-4114-740X

2 Universidade Federal de Alfenas (Unifal-MG), Instituto de Ciências da Natureza, Curso de Graduação em Geografia, Alfenas, Brasil, marcio.vitiello@unifal-mg.edu.br, https://orcid.org/00000001-5624-8601
} 


\section{ENTREVISTA CON LA PROFESORA DOCTORA MARIA ADÉLIA APARECIDA DE SOUZA - PARTE II}

Resumen: Del 10 al 12 de junio de 2019, el curso de Geografía de la Universidad Federal de Alfenas - UNIFAL / MG recibió el V GEOSIMPÓSIO y el III GEOTRANS para discutir los conflictos y desigualdades territoriales en la sociedad contemporánea. Fueron tres días de debates sólidos, centrados en la dimensión política del espacio geográfico y la participación de importantes intelectuales de la Geografía brasileña, como la profesora Maria Adélia de Souza, quien presentó la conferencia de clausura con la necesaria discusión sobre las "Desigualdades socioespaciales y la constitución de lugares en las ciudades". En la mañana del último día del evento, Maria Adélia concedió la siguiente entrevista, en la que retrata su trayectoria en la Geografía brasileña, analiza la crisis que enfrenta esta área del conocimiento y refuerza la importancia de la Nueva Geografía construida por el profesor Milton Santos como posibilidad de superarla.

Palabras clave: Milton Santos. Lugar. Epistemología. Totalidad. Metáfora.

Houve uma expansão no ensino superior público no país neste início de século. Foram criadas dezenas de cursos de graduação e pós-graduação em Geografia - por exemplo, nos últimos quinze anos -, bem como dezenas de universidades federais. A Unifal-MG é fruto dessa política. E agora nós vivemos um momento em que toda essa política de governo está sendo ameaçada. Gostaríamos que a professora comentasse sobre como a gente pode resistir aos processos de mercantilização da educação.

Então, aí entra a questão do lugar, porque eu acho que a esquerda, neste momento tão grave da história do Brasil, não está vendo. O lugar é o espaço da prática política e da resistência. E o lugar pressupõe a intersubjetividade. O lugar é o espaço da intersubjetividade. Vou dar um exemplo de intersubjetividade resistente: o movimento Hip-Hop em São Paulo. Eles têm um curso para os movimentos populares. O pessoal do Fórum Social do Hip-Hop sabe o que é o território usado, sabe a importância da constituição dos lugares que se formam, por exemplo, com os shows. O Mano Brown é o exemplo claro de uma pessoa rígida, rigorosa. Ele deu uma aula de resistência no Rio de Janeiro quando falou: "Vocês ficam aqui e depois vocês vão tomar champagne lá na Vieira Souto. Eu vou lá pra quebrada, correr risco de vida no meio do tráfico e tudo o mais, com quem eu faço política". Ele negocia com traficante, faz política com traficante, certamente, penso eu. Que foi o que, segundo eu soube, o Leonel Brizola ${ }^{3}$ teve de fazer no Rio de Janeiro para conseguir

\footnotetext{
${ }^{3}$ Governador do Rio de Janeiro entre 1983-1987 e 1991-1994.
} 
governar e o Estado entrar nos lugares onde jamais está, usar o território que antes era usado pelo tráfico como governo. Essas coisas não são simples. A política se faz com "p" maiúsculo ou minúsculo, no Rio de Janeiro ou em qualquer lugar do mundo. Depende de quem a faz e de suas intencionalidades! Apenas para introduzir minha resposta à sua pergunta.

Desde 2015 eu deixei a USP. Porque a partir de 1990 a maioria dos meus alunos nunca mais conseguiu uma bolsa de estudos, maioria que vinha de fora de São Paulo e estudava coisas importantes, com projetos bem feitos. Só conseguiam resto de bolsa do CNPq. Da Fapesp, uma raridade! Não nos esquecendo que nós somos o CNPq e a Fapesp! Essa discussão é nossa. Exclusivamente nossa! Comecei a sentir algo muito estranho no ar. Um aluno meu, com prêmio CAPES de tese de doutorado, em 2014, fez seu doutorado sem bolsa de estudos, com tema relevante e pioneiro nos estudos geográficos - estudo sobre o sistema penal brasileiro! Nessa época também, deliberada e majoritariamente, eu tomei outra decisão, que foi a de orientar alunos de outras regiões que não fosse de São Paulo. Eu só orientei alunos do Nordeste, da Amazônia, nos últimos trinta anos. Excepcionalmente paulistas. Depois, o único projeto de estudo do negro que eu fiz com o Milton, que nós dois íamos fazer juntos, e anunciamos isso numa reunião da AGB - porque o Milton frequentava a $A G B$, eu não - , mas o Milton morreu e fiquei sozinha com um belo tema de pesquisa na mão. Mas uma aluna que fez a graduação na Unicamp, enquanto eu era professora lá, se interessou por um dos nossos projetos, pois imaginávamos um grande programa de estudo do uso do território pelos negros no Brasil. Eu até havia conseguido fazer reuniões com os grupos de negros de Campinas para expor essa ideia. A escravidão lá durou um ano a mais. Quando eu tive vaga na pós para acolher essa moça, que esperou anos para ser minha orientanda, ela fez o projeto mas se descuidou num aspecto, quanto às normas burocráticas da Pós-Graduação: em vez de mandar o projeto de pesquisa com vinte páginas, ela mandou 21 páginas e o projeto, excelente, foi desqualificado por uma página pela comissão de seleção. $\mathrm{Na}$ academia e nas agências de financiamento, o pacto político tem o nome de "falta de recursos", "o projeto excedeu o número de páginas solicitado", comissões com mestres examinando projetos de candidato a doutorado, e por aí vai... Por uma página, aquela que provavelmente seria minha última aluna na USP foi eliminada. Então pensei: "Chega! Não dá mais". Os meus alunos todos sem bolsa, ou pegando resto de bolsa, e a minha pressão subindo... Aí 
eu desisti do projeto do negro. Lamentavelmente, pois sem apoio institucional, vale dizer, sem alunos, é impossível você fazer sozinho uma reflexão dessa importância e magnitude! Eu queria que o Renato ${ }^{4}$, que conheci agora aqui em Alfenas, lesse esse projeto.

\section{Essa situação reflete o que está acontecendo hoje nas universidades, de cima para baixo, mas também dentro?}

Então, para voltar às universidades. Eu acho que, talvez por culpa da geração que lutou contra a ditadura, e eu faço parte dela - e lutei mesmo, fiz coisas inimagináveis. Olhando de longe, pois não sou mais militante, e desde a Anistia nunca pertenci a partido político nenhum, exceto a uma organização - a JUC. A Ação Popular, como já disse no início desta entrevista, esquerda da universidade, digo da USP, que conheço melhor, parece estar perdida, sem alternativa. $E$, na dinâmica dos lugares da universidade - eu escrevi um comentário no meu Face sobre isso - lugar como espaço do acontecer solidário anda bem difícil! A universidade e sua política se ideologizaram e se partidarizaram demasiadamente! Os acordos são também controlados fora dos interesses precípuos da universidade. Hoje muito mais do que ontem, pois é claro que a vida política interfere na universidade. Mas atualmente essa interferência é demais! A USP era o meu lugar, lá eu vivi praticamente, cotidianamente, por mais de meio século! $\mathrm{E}$ os lugares que se constituem hoje na USP foram mudando rapidamente, com a política, especialmente a partidária lá existente: visivelmente entre PSDB e PT. Passei a não mais conseguir navegar nessas águas, pois, antes, tanto na política estudantil quanto na política acadêmica - feita por professores, alunos e funcionários, salvo raríssimas exceções - as articulações eram entre as áreas do conhecimento, entre institutos, faculdades e escolas, creiam-me! Era importante na USP articular-se em um primeiro momento com o CAOC da Medicina ou com o Politécnico da Poli, ou mesmo conosco, o segundo maior grêmio da universidade, que era o da Faculdade de Filosofia, Ciências e Letras, assim chamada naquela época, para realizar a política acadêmica e estudantil, em vez da JUC, do PCB, da POLOP ou seja lá o que for que existia na época! Verifiquei que não tinha mais espaço e comecei a

4 Renato Emerson Nascimento dos Santos, professor adjunto do Instituto de Pesquisa e Planejamento Regional da Universidade Federal do Rio de Janeiro (IPPUR/UFRJ), que participou da mesa-redonda "Direitos Humanos e Geografia: questões étnico-raciais e gênero" no V GEOSIMPÓSIO. 
adoecer - literalmente, a pressão subindo de forma incontrolada. Muito difícil viver num lugar onde você não consegue mais constituir lugares. A mudança foi brutal e muito rápida, quanto a tudo! Até hoje acho que eles não perceberam que eu a deixei de lado, desde 2015. Nunca mais voltei à Cidade Universitária. Nosso trabalho, nossas decisões como acadêmicos são completamente diferentes! Temos de ter responsabilidades fundadas no respeito mútuo e na história de cada um dentro da universidade. Escrevi uma carta à coordenadora do programa de pós-graduação ao qual eu estava vinculada, uma jovem professora - como eu já estava aposentada havia mais de dez anos, continuei a trabalhar apenas na pós. Sua resposta foi inacreditável: Como eu poderia deixar a pós sem aviso prévio! Eu nem respondi, mas tenho os e-mails. Há uma falta de compreensão do que seja a vida e a dinâmica acadêmicas! Parece que inventaram a universidade agora! História, rituais, bons modos, convivência na diversidade, nem pensar! Agora ocorrerá na USP o próximo encontro da Anpege $^{5}$, da qual Milton Santos, Amália Inez Geraiges e eu, todos da USP, com colegas da Bahia, constituímos a primeira diretoria. Eu fiz o registro da Anpege em cartório, em São Paulo! E outro dia recebi um telefonema com o seguinte convite: "Professora, a gente queria que a senhora viesse participar de uma mesa-redonda em homenagem ao Milton Santos, no próximo Encontro da Anpege, que será aqui na USP". Respondi: "Gente, uma mesa-redonda para Milton em sua casa? Um ex-presidente da Anpege, um dos maiores geógrafos brasileiros, conhecido no mundo todo, e sua antiga associação o homenageia, em sua casa, com uma mesa-redonda?". Ele merece uma mesa-redonda como homenagem?! Outra coisa que vocês não conhecem, e que eu gostaria de ensinar, é um pouquinho sobre os rituais, as cerimônias e o cuidado com os protocolos acadêmicos. Você tem que saber quem você convida, como e para que convida. Quem, como e quando homenageia um seu colega. Na vida acadêmica, onde o trabalho é exclusivamente individual, pois sua base é estudar, pensar, escrever, tudo é individual, embora depois seja necessariamente compartilhado, socialmente, o que produzimos. Mas 0 esforço é individual, e as homenagens precisam ser individuais também. $\mathrm{Na}$ Geografia eu vejo, desde há algumas décadas, que as homenagens são dadas "às baciadas", coletivas, as vezes para algumas dezenas de pessoas. Parecemos times de futebol! Mas aí de fato o trabalho e o esforço são necessariamente coletivos. $O$

\footnotetext{
${ }^{5}$ Associação Nacional de Pós-graduação e Pesquisa em Geografia.
} 
critério não pode ser apenas político - este é aceitável, mas deve ser presidido por um critério de autoridade acadêmica também no sentido do conhecimento! E não se trata de preconceito contra os jovens ou coisa que o valha. Nós nos reunimos não para dar aula para os meninos, mas para fazer sérias discussões sobre conhecimento "entre pares", e para valer! Quando esse critério não vigora, fica uma conversa entre pais e filhos! Nada de ciência, nada de crítica. Eu só aceitei participar da Mesa de Encerramento do Geosimpósio com o Hervé Théry ${ }^{6}$ porque seria um prazer debater com ele. Porque mesas-redondas precisam ser constituídas por colegas que estão em nível intermediário. Imaginem colocar Milton Santos, Manoel Correia, por exemplo - que não estão mais entre nós -, ou competentes e experientes colegas que podem "conferir" conhecimento, a debater com jovens mestrandos ou doutorandos em mesas-redondas! Se a discussão não for piegas, mas pra valer, coitado dos meninos! Não é arrogância não! É que o processo de conhecimento é longo e profundo! Simples assim. Com todo o respeito, trata-se de um desperdício de tempo e de cérebros! Isso não funciona na academia a não ser para evitar o debate e fazer compadrio! Se os organizadores reconhecem que tem alguém que tem que dizer alguma coisa, ele tem que vir conferenciar, ensinar, não tem que vir debater. Tem que vir ensinar. Nós, geógrafos brasileiros, temos muito o que dizer uns aos outros, e assim com muita maturidade, conhecimento e experiência acumulada, ir institucionalizando as nossas sociedades cientificas. Nas reuniões científicas, as conferências de abertura sempre precisam ser feitas por um de nós, para comunicar aos colegas de outras regiões, de outros países, como anda a nossa disciplina no Brasil. Agora não! Parece que não temos o que dizer para abrir os debates de um seminário organizado por brasileiros e por isso chamam colegas do exterior - com todo respeito que temos pelos seus trabalhos, que lemos, mas boa parte deles não nos leem - para abrirem nossas reuniões! Atitude de "vira-latas", tão comum no Brasil. Não lideramos nenhuma reunião cientifica em país "civilizado", a não ser excepcional e raramente, com nossos raros grandes nomes. É um papel de liderança de conhecimento que não se delega! Aqui é chique ter um colega de fora abrindo nossas reuniões científicas! Dizem até que qualifica ainda mais a reunião... E vejo muitos jovens concordar com isso! Não é xenofobia não. É ritual acadêmico, normas seculares, direito de crescer com as próprias pernas, achar seu próprio

\footnotetext{
${ }^{6}$ Atualmente é professor visitante do Programa de Pós-graduação em Geografia Humana, PPGH (USP).
} 
caminho, liderando o conhecimento autóctone. Difícil libertar-se do colonialismo cultural. $E$, às vezes nossos colegas não nos ajudam muito...Isso eu disse ontem aqui para o Michel7 $^{7}$. Com jeitinho, eu falei: "Olhe, Michel, nós passamos pelos mesmos caminhos e tem um problema.... Eu sou francófona. Morei em Paris dez anos, adoro a França, é minha segunda pátria, conheço Paris e a França como a palma da minha mão. Mas por que eu voltei? Porque percebi que o colonialismo ainda existe lá e que vocês não têm respeito por nós". Aí eu comecei a dizer quem era ele, porque eu fui me interessar em saber quem ele era. Fui ler seus artigos. Eu não o conhecia pessoalmente. Conheci para me preparar para vir a esta reunião aqui em Alfenas. Daí eu the perguntei: "Você sabe quem eu sou? O que é a Geografia brasileira? Por que vocês não nos leem?". Qualquer coisa que saía publicado no mundo inteiro, todos nós, professores de Geografia e nossos alunos brasileiros, tudo nós lemos e mandamos ler. Um artigo em espanhol, às vezes alguma coisa em francês. Às vezes, a gente nem sabia francês. Eu fiz o meu curso de Geografia lendo francês, porque era bibliografia básica do curso. Fomos fundados pelos franceses. Tive que "me virar". Lemos todos e tudo, de David Harvey a Rogério Haesbaert, nosso campeão em venda de livros de Geografia, Rui Moreira, Mauricio Abreu, Pedro Vasconcellos, Júlia Adão, Lia Osório, Jan Bitoun, Berta Becker, Roberto Lobato, Carlos Augusto de Figueiredo Monteiro, Ana Fani, para citar alguns mais conhecidos entre nós e que publicam. Aqui nós lemos os nossos e lemos os colegas de fora! Os intelectuais do Norte, com as exceções de praxe, não nos leem! Não há tempo para comprovar isso aqui e agora. Mas basta examinar a bibliografia de suas obras! Como você pode escrever um livro sobre epistemologia do espaço geográfico depois de 1974 e não citar, quero dizer, não discutir ou fazer alguma referência à obra de Milton Santos? Entendo que só pode ser por ignorância ou preconceito! Veja se ele está em Harvey, em Soja, em Doreen Massey, que lemos insistentemente! Especialmente depois de 1974, não se pode mais deixar de falar e, sobretudo, discutir a Geografia brasileira, quando se trata de refletir sobre qualquer aspecto da epistemologia da Geografia. Digo 1974 tendo como referência a obra Geografia Nova, escrita por um geógrafo que morou anos fora do Brasil, um exilado que ficou de certo modo conhecido por lá! Mas eu poderia citar outros tantos! Estou muito à vontade nesse debate, pois não público livros, meu caminho até agora

\footnotetext{
7 Professor Michel Lesourd, da Universidade de Rouen, que na conferência de abertura do $\mathrm{V}$ GEOSIMPÓSIO e do III GEOTRANS discorreu sobre conflitos étnicos e regionais a partir das crises do modelo do Estado-Nação em países do Oeste Africano.
} 
foi outro. Mas meus colegas publicam! Ainda que nosso trabalho não seja reconhecido por eles, buscamos na França, na Inglaterra e nos Estados Unidos as nossas inspirações! Nada a dizer? Ou estou com minhas leituras atrasadas? É esse grande problema que temos e que chamo de falta de institucionalidade da Geografia. Fiquei desesperada quando li sobre o Epistemologias do Sulo de Boaventura de Sousa Santos! É disso que se trata. O que é isso? Epistemologia do Norte e do Sul? Isso não é sinônimo de soberania, nem de descolonização, nem de liberdade para conduzir cada um seu próprio pensamento, seu próprio conhecimento em um mundo global, universal. Hoje mais do que nunca!

\section{Há um texto do professor Milton Santos em "Epistemologias do Sul”. É uma coletânea de textos de autores do Sul.}

Mas não existe epistemologia do Sul. Há uma única epistemologia. Porque o que se discute na desigualdade é o diverso no todo, não é? Por que nós somos pobres? Porque o outro é rico. E o outro faz parte da outra face da moeda. Então você tem que trabalhar com essa ideia de totalidade-mundo. A expressão epistemologia do Sul poderia ser substituída por "epistemologia" pura e simples ou por um "saber libertário", descolonizado.

\section{Professora, e em relação às redes sociais? A senhora está com um canal no Youtube e sempre o usa para postar vídeos curtos. Poderia falar um pouco sobre essa experiência?}

Eu pensei em fazer alguma coisa porque precisava continuar trabalhando depois de 2015, quando deixei a USP. Não sou daquela lista que o Carluxo, o Número 01, publicou [risos]. Tenho dois filhos, e quando filho passa apuro é o pai e a mãe que têm de ajudar, não é? Me cortaram a possibilidade de fazer pesquisa. Cheguei até a montar um Instituto. Mas aí o que fez a Fapesp, onde inscrevi o Instituto como uma sociedade cientifica, sem fins lucrativos, para continuar a fazer pesquisas e formar pesquisadores. Ela dava bolsa de estudos, dinheiro para certas despesas de pesquisa, especialmente trabalho de campo, para que eu formasse pesquisadores todos os pedidos que encaminhei foram atendidos -, mas não havia dinheiro para o custeio do Instituto, que não estava alojado em uma instituição pública, como muitos

\footnotetext{
8 Livro organizado por Boaventura de Sousa Santos e Maria Paula Meneses, lançado pela Editora Cortez (2009), com uma coletânea de textos de autores do "Sul", como Milton Santos, Kabengele Munanga, Nilma Gomes, Anibal Quijano, Amina Mama, Shiv Visvanathan, entre outros.
} 
que eu conhecia naquela época. E pesquisador traz gastos para as instituições ao realizarem suas tarefas em seus recintos: água, telefone, luz etc. Eu nunca trabalhei para a iniciativa privada e nunca dei consultorias para empresas e órgãos internacionais, que, aliás, pagam muito bem. Esta seria uma alternativa para viver e ganhar bem! Mas jamais o fiz! "Me empresta teu currículo que eu vou entrar numa licitação na África." Um mês atrás fui procurada por um consultor. Ele falou: "Adélia, estamos querendo entrar num projeto grande, na Cidade do Cabo. Você não quer entrar conosco? Você não precisa fazer nada. Você só empresta o seu currículo de geógrafa e planejadora! Seu currículo vale ouro"! Só não vale em Belo Horizonte [risos]. Mas isso eu não aceito. Nunca aceitei. Nunca trabalhei para a iniciativa privada ou para órgão internacional, porque os órgãos internacionais defendem sempre os interesses das grandes empresas. Ou não? O Fundo Monetário... Ou não? O Banco Mundial... Ou não? Ingenuidade? Não, visão de mundo. E aí eu fiquei com fama de insuportável, intratável, radical e outras qualificações. Ninguém tem que ser como eu, mas tem que respeitar minha coerência. Não me falta trabalho, nunca! Mas você trabalha de graça, dizem muitos. E é verdade! Sou funcionária pública, professora e pesquisadora formada com dinheiro público e acho que devo trabalhar sim, e de graça, para as instituições públicas! Fiz uma conferência na Escola de Teatro de São Paulo. Teatro lotado. Para ouvir falar do lugar, espaço da resistência. $\mathrm{E}$ a resistência se dá pela política. E é isso que o capitalismo está exigindo da gente, a prática política na constituição dos lugares. Usar o território politicamente. Constituir lugares. Senão, nós não vamos sair dessa. Festa, bandeira ou multidão na rua, que é um megalugar. A constituição do protesto é a constituição do lugar. Mas ainda não estamos conseguindo fazer essa discussão. A dita Geografia Urbana trilha outros caminhos. Por ainda ter muito que ensinar, por ainda ter agenda lotada de convites, mas por estar sem instituição é que decidi usar os vídeos do Youtube para ensinar. E tem tido excelente aceitação. Eu, em meio a essa confusão decidi também, agora, escrever meus livros e contribuir para o avanço teórico, epistemológico e para o conhecimento dos temas que estudei na Geografia e no Planejamento Territorial para e sobre o meu país.

Nós, da universidade, temos que ser críticos. Aí eu sou "azeda"!

Quando o Paulo Markun, que é um grande jornalista, me convidou para fazer profissionalmente o plano de governo do Gabriel Chalita, que concorreu ao cargo de prefeito de São Paulo em 2012, eu cobrei, claro, e o plano foi muito bem feito! Ele, o 
candidato que não pode ser um fascista - para esses eu não trabalho -, me oferece as diretrizes políticas, que discutimos sempre em reuniões políticas com as direções partidárias. Então verei se minhas ideias podem trabalhar com elas. O que o candidato me dá são diretrizes políticas, democráticas e de combate à desigualdade. Aí eu trabalho. E nenhum daqueles para quem trabalhei em suas campanhas Montoro, por dois anos e de graça, Luiza Erundina em 2000, por três meses e de graça, Paulo Skaf e Gabriel Chalita profissionalmente - interferiu no meu trabalho. Com todos eles eu tive toda a liberdade para fazer minhas propostas, e com elas seus marqueteiros políticos elaborarem seus programas de TV. E assim fomos... Veja qual é a minha fama! Paulo Markun, antes do encontro que teríamos com o Chalita, me disse após seu convite: "Adélia, você me desculpe, mas eu vou fazer a sua apresentação para o Chalita". Eu nunca tinha visto o Chalita na minha vida! "Olha, Chalita, Maria Adélia é planejadora urbana". De fato, aliás, sou talvez uma das raras pessoas no Brasil que estudaram Planejamento Territorial, como era chamado no IRFED, onde fiz o curso de Especialização, como se dizia naquela época. A grande maioria dos ditos planejadores estudam nas escolas de Economia, Arquitetura e Urbanismo. O Markun continuou: "Ela fez o plano de governo do Montoro, que foi vitorioso. Agora, ela tem uma característica, viu, Adélia", disse ele. Ele falava assim. E o Markun mais jovem, como jornalista e repórter, me entrevistou nos cargos públicos que eu tive. E ele tem o maior respeito por mim, como todos os jornalistas do passado que conheci e que são até hoje meus amigos no Face. "A Maria Adélia, Chalita", prosseguiu Paulo Markun, "a fama que ela tem é que ela é insuportável, intratável e impermeável". Eu falei: "Markun, por que você não põe 'amável'? Porque tem o sufixo vel também". [risos].

O Chalita deu uma risada e eu disse: "Olha, eu sou mesmo. Agora, eu tenho um outro atributo, que é lealdade. Se eu topar trabalhar com você, pode contar comigo que eu não vou te trair. Agora, a conversa é sempre dura. As propostas que eu fizer para você, eu vou advogar a favor delas em seu benefício e para o bem do povo de São Paulo. O meu compromisso não é com você, é com o povo de São Paulo".

E ele topou. Eu vou falar disso hoje na minha conferência: O que um geógrafo pode fazer pela cidade São Paulo até chegar à intervenção comandada pelo prefeito? Para resolver não só o problema da habitação. E eu vou anunciar um conceito, aqui, que eu chamo - não está bom, talvez eu mude - , que se chama Complexos 
Territoriais $^{9}$. E é sobre a fundamentação de todo o meu trabalho que falo nos meus vídeos no Youtube.

\section{Como é que as redes sociais podem contribuir para essa resistência?}

Eu amo o Facebook. Vocês não imaginam os desaforos que eu recebo, os xingamentos que eu recebo no Facebook. Quando o xingamento é pessoal e desonesto, eu bloqueio a pessoa. É um poder que eu tenho! Acho que o único [risos]. E o Face é democrático. Agora, você tem que ter tempo e estômago. Eu decidi fazer uma experiência com meus vídeos. Foi interessante, pois há vídeos meus que deram mais de mil visualizações em pouquíssimo tempo. Eu sou um dos milhares de youtubers que existem e estou no i-territorial, nome que dei ao meu canal. Já gravei o quê... uns cinco ou seis vídeos. Fiz um sobre eleição. Mas não como cientista política. O que eu quero é que as pessoas entendam que os geógrafos bem formados usam os seus conceitos e para ajudar a compreender todos os temas da atualidade que implicam a vida humana na superfície do planeta usando o território. Eu não preciso tomar emprestado o conceito de poder - os conceitos da economia, por exemplo. Uso os conceitos geográficos. Lugar, região, paisagem, meio, meio natural, meio técnico e as outras coisas que o Milton foi sugerindo: verticalidades, horizontalidades, tecnoesfera, psicoesfera, racionalidades, contrarracionalidades e por aí vai. Eu tenho um texto de que gosto muito, que foi uma crítica que fiz ao Roberto Lobato, um dos grandes geógrafos brasileiros. Ele é muito estudioso, mas não é um autor criativo. Ele tem outro atributo, outro tipo de inteligência. O Milton e eu temos inteligência criativa, e a do Roberto Lobato é incrível e privilegiadamente armazenativa. Um erudito, segundo a leitura que faço dele. Então, a gente junto dá uma combinação maravilhosa. E o Roberto escreveu dois livros, um intitulado Sistema Urbano, o outro, Rede Urbana. Livros pequenininhos, assim, brancos. Tentei, a partir desses livros, avançar um pouquinho. Eu gosto muito dele, eu lia e leio tudo o que ele pública. Quem me apresentou a obra de David Harvey, nos idos da década de 1970, quando morei no Rio de Janeiro, foi o Roberto. O primeiro livro do Harvey que eu tenho, Explanation in Geography, foi ele quem me deu de presente. Quando o Harvey deixou de ser liberal e virou marxista. Aí eu fiz uma crítica aos dois livros de Roberto Lobato a

\footnotetext{
${ }_{9}$ Decorrido um ano, ao fazer a revisão do texto da entrevista para publicação, a professora mudou o nome para Territórios da Cidadania e da Existência.
} 
partir da intromissão da tecnologia nas nossas vidas e o quanto a alta tecnologia muda a relação espaço-tempo ${ }^{10}$. Hoje você tem uma sobreposição tempo-espaço. Eu sempre dou como exemplo: sou corintiana roxa. Não atendo nem minha mãe, se ela me ligar, se o Corinthians estiver jogando e eu estiver vendo ao vivo, não no Itaquerão, mas em casa, em tempo real, o meu Coringão jogar. Eis o milagre da técnica! Agora, o que estou dizendo? Eu posso assistir em tempo real, de onde estou, o que está acontecendo naquele tempo, em outra localidade. $E$ isso é sobreposição espaço-tempo. São espaços distintos no mesmo tempo. Isso muda a visão de mundo e muda a Geografia. Se você tiver uma câmera ligada no mundo, aqui e agora, ou seja, eu em casa, o Corinthians no Itaquerão, espaços diferentes, mas no mesmo tempo. O que é o videoface? É isso, espaço/tempo sobrepostos e com imagem. Com a visão do real concreto, ao mesmo tempo, em espaços distintos! Eu falo, ainda que menos do que eu desejaria, com meus colegas e amigos do mundo inteiro. Eu acordo, às vezes, um colega que tenho no Japão, quando me esqueço dos fusos horários! [risos], pelo videoface, para realmente matar a saudade vendo-o em tempo real.

\section{E como fica a constituição dos lugares nesse novo tempo-espaço?}

Hoje você constitui lugares também virtuais. O que é preciso para você constituir um lugar? A intersubjetividade. Eu falando com você em tempo real. Esteja você aqui ou esteja lá onde for. A existência da comunicação é a mesma temporalidade presencial ou virtual. O que constitui o lugar é a comunicação. Aí tem que ler um livro do filósofo francês Gilbert Simondon, Do Modo de Existência dos Objetos Técnicos ou La Individuación a la Luz de las Nociones de forma y de Información. É um filósofo da técnica. Mas também tem que ler o Milton Santos, Técnica Espaço Tempo Globalização e Meio Técnico-científico Informacional; Vilém Flusser, 0 Mundo Codificado: Por uma Filosofia do Design e da Comunicação; Noam Chomsky, Mídia: Propaganda Política e Manipulação, François Dosse, Renascimento do Acontecimento, Augustin Berque, Poétique de la Terre, entre outras coisas que tenho lido para fazer, hoje, o meu trabalho de amadurecimento e compreensão da Geografia do presente.

\footnotetext{
${ }^{10}$ Essa crítica foi feita em um artigo intitulado "Conexões Geográficas: um ensaio metodológico (uma versão ainda preliminar)", publicado no Boletim Paulista de Geografia n. 71 (primeiro semestre de 1992), São Paulo, AGB.
} 


\section{Há uma resistência com os intelectuais, então?}

Com quem sabe, sim. Com quem anuncia o novo, não a novidade. Como, por exemplo, o esforço que estamos fazendo para entender o papel do lugar na nova epistemologia da Geografia. O que é o lugar? O lugar é a localidade da prática política. Há diferença entre lugar e localidade. A localidade tem referenciamento geodésico e dá nome à localidade onde você nasceu. Eu nasci em Espírito Santo do Pinhal, você nasceu em Alfenas, nossas localidades de nascimento...

Então, nós nascemos em localidades que são mundialmente conhecidas e georreferenciadas, inclusive, por uma toponímia. Nas localidades, a gente constitui lugares. Qual é a localidade onde nós estamos? É Alfenas. A primeira aula que tínhamos dado, antigamente, no curso de Geografia, na Cartografia era aprender sobre sistema geodésico: tantos graus de latitude norte e longitude oeste. Isso é uma localidade. Está escrito na minha carteira de identidade: "Lugar de nascimento". Está errado. É localidade. Para você ver, antes do Milton Santos era tudo conceitualmente muito misturado na Geografia. Fala-se em espaço, território, lugar, tudo quase que como sinônimos! Eu, já me atualizei na Geografia, uso conceitos precisos e busco não me equivocar. Meu método de pesquisa, de fato, é um sistema coerente de ideias.

\section{O que a senhora diria aos nossos alunos que estão começando a estudar Geografia hoje?}

Primeiro, cumprimentá-los pela escolha. Segundo, que saibam que há tudo por ser refundado na Geografia. O que nós aprendemos, o que eu aprendi já não serve mais. Eu sou geógrafa graças à velha escola de Geografia, mas não consigo mais prosseguir com ela, interpretar e ser geógrafa no século XXI com a Geografia que eu aprendi com Pierre George, com Michel Rochefort, com Jean Tricart, toda essa gente de enorme valor, que foram meus professores e a quem eu devo quem sou. Só que o mundo andou, e hoje a Geografia precisa ser refundada e reestudada. E nós temos a chance de ter o maior geógrafo contemporâneo escrevendo em português para quem quiser estudar, desde que não tenha preconceito de qualquer natureza, de raça ou de conhecimento novo, e desde que procure entendê-lo, o que não é fácil, porque ele fez aquilo que um geógrafo de hoje não precisou fazer, que foi estudar filosofia e tudo o mais para propor que a Geografia é a ciência que compreende a vida humana na superfície do planeta. É disso que trata a Geografia. 
Antes era descrever a vida humana na superfície do planeta. Depois, foi explicar a vida humana na superfície do planeta. Hoje, você não explica certos processos, porque eles são inexplicáveis. Por que eles são inexplicáveis? Por isso que é bom ler o Gilbert Simondon e o Max Horkheimer sobre esclarecimento. O que é esclarecer? E o Charles Sanders Peirce. Você tem de ler autores que o ajudam a aprimorar o seu intelecto e aprimorar com esse diálogo o desenvolvimento e a prática da sua disciplina. O Milton, por exemplo, é mais citado e usado hoje pelo pessoal da Comunicação, pelo pessoal de Teatro do que pelos próprios geógrafos e muitos cientistas sociais. A Ciência Política nos desconhece completamente! Hoje eu vou criar uma discussão com o pessoal da Geopolítica, da Geografia Política, porque eles não leram a obra do Milton. Estão, ainda, no início do século XX, final do século XIX. E o que o Milton entendeu? Que a tecnologia faz a produção das paisagens humanizadas girarem quase que na mesma dinâmica do mundo. Se você tem a condição tecnológica de implodir, com um avião, duas torres em Nova York, mudar a paisagem da cidade de Nova York, e como aquilo também é simbólico, você mudou o mundo. Como é que você vai explicar isso como geógrafo tradicional? Você tem de filosofar.

\section{E de onde vem essa resistência?}

O mundo depende do conhecimento geográfico, não mais apenas da Ciência Política. Porque a Geografia é irmã siamesa da Política. A Política não pode viver sem a Geografia, e a Geografia não vive sem a Política. Nós, com o Milton, chegamos à Política, mas a Ciência Política ainda está fazendo estudos comparativos, analíticos! Num mundo em confronto acelerado na sua dinâmica, não há tempo para o método analítico. O método da Política, por isso mesmo, precisa ser outro! E, como dizem os jovens, "tome" hermenêutica e dialética para compreender o mundo! O geógrafo não pode mais fazer estudo comparativo. Você pode, desde que você diga: é uma perspectiva analítica, ela diz respeito a tal data, e você vai descrever uma paisagem que muda a cada instante. Ela pode não mudar pela forma, mas muda pela estrutura e pela função. Muda com o processo do mundo, hoje cada vez mais acelerado. A paisagem urbana, por exemplo, muda aceleradamente. Você anda numas ruas aqui de Alfenas, de dia está lotado de carros, você vai lá à noite e não está. Se você falar que em Alfenas tem uma intensidade de tráfego, você vai ter que dizer quando. E observar sobre tudo o que 
não é normal e permanente. Quando não há teoria para compreender essa aceleração, a descrição não ajuda em nada. Enquanto você a descreve, a realidade já mudou. Por isso os quantitativos estão cada vez mais longe de nos ajudar a compreender o mundo. Como é que a gente vai fazer, como geógrafo, para explicar tamanha complexidade? Só teoricamente. Mas nós precisamos da empiria. A Geografia é uma ciência empírica desvendada hoje, necessariamente, por uma teoria. Eu vou falar disso hoje na minha conferência. Eu uso mapa para fazer Geografia. Estou adiantando a minha conferência [risos].

Gente, eu trouxe um mimo para vocês. É a conclusão de um dos meus livros. Pois, sendo a Geografia uma filosofia da técnica, e filosofar é pensar o futuro, isso facilita em muito o meu trabalho como planejadora. O Milton diz: a Geografia tem uma âncora do futuro. Por quê? Porque o presente dinâmico, ele tende a quê? Você vai dizer: "Ah, com o Bolsonaro a gente deu uma 'marcha à ré'. O Bolsonaro e o sistema político que ele tenta implementar deram marcha à ré, mas ele não consegue abranger de forma plena uma totalidade em movimento. Na história recente mudam governos, mas nada muda para a maioria pobre. Que famélicos, logo sábios, para conseguir comida aceitam ser comprados por comida, isso eu sou capaz de compreender! Mas os complexos planos de governo não os atingem! Ou será que incomoda ao pobre que a inflação seja 10, 15, 20 ou 35\% ao dia? Ele vive sempre do mesmo jeito, sempre segurando a onda. Um pequeno detalhe, então: é por isso que há esperança na fundação de uma pedagogia da civilização a ser viabilizada pela constituição de lugares para concebê-la com aqueles que dominam a capacidade de resistência e de sobrevivência. Os lugares estão à disposição como ferramenta da política, basta provocar a sua constituição nessa perspectiva. Isso é o período popular, que aliás já está aí, pois os pobres são resistentes, eles criam desde sempre lugares de resistência. Basta conviver com eles, aprender sobre suas práticas, incorporá-las e divulgá-las para a maioria e ir aprimorando. Isso já está sendo feito nas periferias das grandes cidades, absolutamente abandonadas pelos governos e pelo dito "poder público". Os pobres dividem comida, encontram-se com a ilegalidade para sobreviver. Por quê? Porque ele sabe constituir lugares, sabe fazer pactos, sabe fazer política na escassez! Eu vou trazer a palavra pacto, hoje, na minha conferência. Há algo mais político do que um pacto? Estou falando sobre pactos territoriais, não setoriais e classistas. Pactos com vistas a lidar com a 
totalidade mundo valendo-se do espaço geográfico no novo discurso político, historicizado como território usado.

\section{De onde a senhora acha que vem, em grande parte, essa resistência ao pensamento do Milton?}

Eu acho que é preconceito colonial. Vem da prática da bestialização, da bestialidade. E aí você tem que ler o Frantz Fanon. Tem a obra dele inteirinha na internet. Ele tem dois livros, Pele Negra, Máscaras Brancas e Os Condenados da Terra, com prefácio de Jean-Paul Sartre, e muitos artigos. Preciosidades para compreender o Brasil. E o Frantz Fanon é martiniquenho, médico, psiquiatra, e para mim ele é quem melhor explica, filosoficamente, o problema do colonialismo e o problema do preconceito, do racismo. Fanon era negro! Fanon e Aimé Césaire, também da Martinica. Intelectual e poeta de primeira grandeza.

Depois do Mercantilismo, o que a gente não sabe é que o grande e terrível preconceito passou a ser contra os pretos e os árabes. Os governos coloniais nos países árabes castravam homens e mulheres para que não se reproduzissem. Isso é milenar. Já os pretos, como eram fortes, foram usados como escravos para trabalhar em situações de penúria. Então é muito complicado. Ao fazer isso, diz o Fanon: "Eu sou colonizador. Eu vim com os navios e as caravelas colonizar o Brasil ou colonizar a África". Quem ficava aqui, no nosso caso, eram os degredados portugueses. Você imagina por que era um degredado: primeiro, porque tinha sido preso como ele era, com o que ele trazia. Estou fazendo essa pesquisa nos arquivos da Universidade de Coimbra para o meu livro de Geografia do Brasil. Estou lendo os manuscritos, as cartas da ralé. Nunca foram consultados. E isso é o que tenho feito, mas sem vínculo institucional, então eu não posso pedir auxílio à pesquisa, eu tenho que pagar a minha pesquisa, porque tem que ter vínculo para pedir à Fapesp ou ao CNPq recursos para a pesquisa. E o Laboplan ${ }^{11}$, me perguntam? O Laboratório de Planejamento, que coordenei por longos e produtivos anos lá na Geografia da USP... não me disse nem "até logo". Guardei lá um material e depois que me aposentei esqueci de ir buscá-lo. Não era material meu, mas da Anpege, da Anpur, inclusive uns vídeos gravados de todos os eventos que eu e o Milton fizemos, que eu paguei com o meu próprio dinheiro. Daí o pessoal pegou esse material, doou

\footnotetext{
${ }^{11}$ Laboratório de Geografia Política, Planejamento Ambiental e Territorial.
} 
parte dele ao IEB e queimou muita coisa, segundo me informaram. Coisas minhas e do Milton! E a sala que eu, quando prefeita da USP, reformei para ser usada por quem assumisse a presidência das nossas associações cientificas, às quais os geógrafos são filiados, AGB, Anpege, Anpur ou seja lá o que fosse, para que tivesse uma sala para acolher a associação lá dentro do Departamento... Milton e eu ficamos quatro anos dirigindo sociedades científicas, e a gente usou aquela sala. Quando terminou a nossa gestão, deixamos a sala e as memórias da gestão lá para quem a ocupasse. Isso fazia parte da memória do departamento. Ou Milton e eu não fazemos parte dessa história? Aquela sala existia para distinguir a instituição da pessoa. Ocuparam essa sala, não cuidaram de mantê-la para o departamento e jogaram tudo no lixo. Hoje, informaram-me que virou sala de material de limpeza, da terceirizada que faz a limpeza do prédio. Se for verdade, precisa de algo mais emblemático para compreender o respeito e a memória pelo o uso do território do prédio da Geografia por dois de seus professores? Os meus vídeos, que são meus, eu posso provar que os paguei ao Benê, meu amigo da História, que fez todas aquelas gravações dos eventos. Eles os mandaram, sem me consultar, para o IEB ${ }^{12}$. Reclamei ao IEB, que ainda não me respondeu, através de um ex-aluno que lá trabalha. Mas o fiz por telefone, não formalmente. $E$ as coisas minhas e do Milton queimaram, queimaram com fogo! E nosso lugar, sim, nosso lugar, hoje virou depósito de material de limpeza, numa universidade onde lugar para professor trabalhar vale ouro. Assim dirigem a universidade hoje, nossos colegas. Sim, colegas, pois são professores.

\section{Quem da USP continua dando continuidade ao pensamento do professor Milton Santos hoje? Os ex-orientandos, Maria Laura Silveira e Fábio Contel, por exemplo, continuam?}

Eles pensam que continuam, mas eu acho que não. Maria Laura não está mais na USP. Nos deixou faz tempo.

O que faz você dizer que algo é ou não é, é a prática, não a intencionalidade. De intencionalidade não tem um ditado popular antigo que diz: "De boas intenções até o inferno está cheio". Imaginem vocês que houve no departamento de Geografia da USP uma reunião sobre história do pensamento geográfico para discutir a influência

12 Instituto de Estudos Brasileiros (USP). 
francesa na Geografia brasileira, tema mais do que pertinente. Como é que se montou a Mesa? Prova cabal de que Milton morreu lá, sem deixar discípulos, seguidores, no sentido mais nobre da palavra, que envolve também fidelidade. Para discutir a influência da Geografia francesa no Brasil, foi montada uma Mesa só com franceses! E, pior, os franceses, pelo que sei, aceitaram! A Marie-Claire Robic, que eu leio e sigo, e o Paul Claval. Agora, com todo o respeito, qual a influência da Geografia francesa na Geografia brasileira? Quem tem de dizer somos nós, os influenciados, sobretudo. Não apenas os influenciadores! Que autoritarismo é esse? O que é uma Geografia Cultural? O que é uma Geografia Urbana? O que é uma Geografia Industrial? Hoje há uma Geografia brasileira, inspirada em autores do passado - falo de Sorre, de Pierre George, de Tricart na geomorfologia, de Monbeig aqui na nossa Geografia Humana. Indubitavelmente, temos como dialogar com os franceses! Mas não houve diálogo! Milton ficaria envergonhado e reagiria firmemente, como eu fiz, ainda que por e-mail ou por telefone, não me lembro mais. Aliás, uma Mesa assim ele não permitiria! Evoluímos, e muito, a partir da Geografia francesa, pois temos uma Geografia que também precisa explicar a transformação, a exploração dos recursos da natureza e trazer para a segunda natureza não apenas as paisagens originadas do mercantilismo e da industrialização. Essa é a Geografia da nossa escola, da escola do Milton, que nós precisamos explicar aos franceses. Nada do que eles possam nos dizer nós não sabemos. Estudamos e lemos tudo deles. E eu não tenho mais amarras. Custei a me descolonizar geograficamente. Não posso ter amarras, senão eu não posso fazer a crítica. 0 único lugar onde você pode fazer a crítica, e se tem obrigação de fazê-la, é na universidade, porque o nosso método precisa ser crítico. O conhecimento exige o método crítico para avançar. Lamentável não ter havido uma boa discussão na Mesa com os franceses. Não assisti, não tive notícias, não soube o que houve. Deduzo que tenha sido um belo monólogo francês, apesar da qualidade dos convidados.

\section{Sim, a gente precisa ir mais a Campinas. [risos]}

A vida me deu presentes tão grandes que eu não posso trai-la. Aqui eu sou uma fênix.

Quando venho a Minas, você pode ter certeza de que eu vou dar um salto. Toda vez que me sinto injustiçada, eu venho a Minas. A outra vez fui convidada pela Assembleia Legislativa de Minas, onde não conhecia ninguém. Só que tinha um 
amigo, Mauro Santayana, que é um grande jornalista, por quem eu tenho o maior respeito, que organizou uma reunião para discutir a questão da soberania nacional e a Amazônia. Aí ele me ligou e disse: "Adélia, eu queria te convidar...". Eu falei: "Mas eu não estudo essas coisas assim, eu sou planejadora". "Mas você não sabe?" "Claro, conheço um pouquinho dessa temática, mas não estudo isso especificamente, e tem uma regra que você tem que pegar na academia, com as pessoas que estão pesquisando o tema que você quer discutir ou conhecer. Eu não sou dessa área de pesquisa, mas tenho minhas ideias! Por exemplo, não concordo com a Berta Becker, minha colega, grande pesquisadora da Amazônia e que fala em gestão do território. Não é o território que você gerencia, é o seu uso. Percebe? Se você fala em gestão do território, você despolitiza a discussão, porque ninguém sabe o que é... Foca na discussão sobre a gestão e se esquece da sociedade! O que é território? Aí o cara fala que é espaço. O método é um processo de construção de organicidade de conceitos. E o conceito é aquela coisa que faz você quase entender a realidade. Mas por que você não entende? A realidade é dinâmica. Quando você chega a ela, ela já mudou. Ou você tem isso na sua cabeça ou nunca vai saber o que o que está pesquisando ou dizendo, e como pesquisar. Só sei que participei da mesa na Assembleia Legislativa de Minas Gerais, sentindo-me honradíssima, mas constrangidíssima, ao lado do professor Celso Furtado, meu orientador de mestrado, que eu não via há décadas! Em Minas Gerais!!!! Mesmo com reprovação em concurso para professor sênior na UFMG!

E Minas Gerais não me abandona, além de Campinas me abrigar para estudar muito e fazer com competência o que faço. A fênix, novamente, reaparece!

Agora, quando revejo essa entrevista para publicá-la, posso acrescentar que há quinze dias fui convidada por alguns colegas do departamento de Geografia da UFMG, por intermédio da professora Valéria Roque, para dar a aula de abertura do curso de Licenciatura desenvolvendo o tema "As categorias de análise do espaço geográfico", aula realizada através de uma Live com mais de novecentos assistentes e que acabou virando uma aula aberta pela internet. Para quem foi reprovado lá... Presentes que a vida me dá.

\section{É a mesma perspectiva de dizer que é o homem que destrói o meio, quando o homem você despolitizou.}


Claro. Naturalizou. Foi isso o grande golpe do Banco Mundial para a questão ambiental. E todo mundo embarcou nessa! Basta retomar as discussões havidas na reunião de Estocolmo nos anos 1970. Então você criou uma questão ambiental que desfocou a discussão sobre as barbaridades do capitalismo, que é sobre a questão social e não a ambiental! Além do equívoco do conceito - mas isso é uma discussão de natureza filosófica que não dá para fazer aqui. A Amazônia não é um ambiente; a Amazônia é um meio natural com qualidades ou, como diz o professor Aziz Nacib Ab'Saber, é um complexo morfoclimático. Por que não respeitar os geógrafos? Mas depois até o professor Aziz embarcou na questão ambiental! É fácil constatar que a questão ambiental passou a ser a palavra mágica nos projetos para ter projeto aprovado em muitas áreas, e não apenas na Geografia, junto às agências financiadoras. Ambiente, e o horror do "meio ambiente" - o que é isso, afinal? Casamento de elefante com borboleta? Meio ambiente?! O que é meio? Eu sou a única geógrafa que escreveu uma crítica a isso, num texto publicado na revista Cronos $^{13}$, da UFRN, intitulado "Meio ambiente e desenvolvimento sustentável. As metáforas do capitalismo", onde exponho as razões pelas quais eu me nego a fazer da metáfora um objeto ou conceito científico. Mas esse procedimento equivocado banalizou-se tanto na ciência quanto nos discursos políticos. Essa e outras metáforas - linguagem simbólica, subjetiva, para falar da realidade concreta - , tais como segurança alimentar, inclusão social, mobilidade e por aí vai. Os problemas vão adquirindo sentido metafórico, não científico... e assim caminha a humanidade na produção do conhecimento técnico e científico, acumulando equívocos, desfocando e despolitizando as discussões. Não é um conceito, uma formulação teórica. A metáfora é uma figura de linguagem. As metáforas não permitem a construção do MÉTODO, que se baseia em construções de ideias decorrentes da observação da realidade concreta, como sistema coerente de ideias. As metáforas podem ter milhares de interpretações. O conceito é uma ideia firme, comprovada subjetiva e objetivamente! Então, nessa perspectiva metafórica, na Geografia banalizada, que é a forma que muitos encontraram para banalizá-la, fala-se inclusive em "desenvolvimento territorial"! O que é desenvolver o território? Do mesmo modo, o que é a "gestão do território"? O que é território, ainda para a maioria dos geógrafos? Eu defendo que, a partir da proposição de Milton e depois me

13 Cronos, Natal-RN, v. 10 , n. 2, p. 101-117, jul./dez. 2009, "Meio ambiente e desenvolvimento sustentável. As metáforas do capitalismo". Maria Adélia Aparecida de Souza (USP). 
distanciando dela, o território sim somente existe quando usado, e eu afirmo que ele - o uso - é um direito existencial que passa lamentavelmente para o foco da luta social, o direito a seu uso. Então o que se multiplica - não se desenvolve - são os usos, não o território. Ele em si não existe, como o espaço geográfico. Não é mais possível banalizar a Geografia com sofismas! Mas então, debatamos! Agora o professor Bernardo ${ }^{14}$ trouxe para este Geosimpósio exatamente esse conceito de desenvolvimento territorial que estou propondo discutirmos aqui. Para mim é igual a desenvolvimento humano. O que é isso? $\mathrm{O}$ que quer dizer desenvolver humanamente? Quando fazemos essa pergunta, a resposta é: "É ele ter condições de saneamento". Mas isso não é desenvolvimento humano, isso é desenvolvimento das empresas e ação do poder público, que não fazem o que deveriam fazer. Com metáforas você escamoteia o método, deturpa o método. Para a ciência, para a produção do conhecimento profundo, isso é um crime. Você tem que estudar, e os professores e cientistas precisam estudar! A política, essa é outra carreira! $E$, quando se quer ser um intelectual público, como dizia o Milton, ou orgânico, como dizia o Gramsci, a responsabilidade, a exigência de conhecimento são ainda maiores!

Porque você tem que acolher um aluno ou um colega respeitando-o criticamente. Isso é ético! Serei eternamente devedora a Milton Santos, que sempre teve a generosidade de criticar meus textos e minhas pesquisas. E me criticava sempre! Bastava eu lhe passar um texto, um projeto de pesquisa, para ele fazer exatamente isso. Eu tenho muitos dos nossos colóquios gravados. Neles, a crítica dura e impiedosa sempre aparece. Entre nós, a palavra de ordem era: "Então defenda-se". E eu faço hoje o que eu aprendi com ele, com os colegas - com respeito, mas no meu estilo. Quando encontro um colega cujo discurso é integro, embora o texto científico ainda seja frágil, eu vejo nele a possibilidade de um bom combate teórico para testar minhas ideias. Por isso vivo fazendo provocações a colegas ilustres, dos quais posso discordar, mas a quem respeito. O bom combate é a arma maior da Ciência e da Política.

\footnotetext{
${ }^{14}$ Bernardo Mançano Fernandes, professor associado da Universidade Estadual Paulista Júlio de Mesquita Filho, Faculdade de Ciências e Tecnologia de Presidente Prudente (SP), que participou da mesa-redonda Movimentos Socioterritoriais na América Latina no V GEOSIMPÓsıO.
} 
Eu não sei, mas toda vez que venho a Minas travo um bom combate. Um deles foi na Assembleia Legislativa do Estado de Minas Gerais, tempos atrás, como referi anteriormente.

\section{Nossa! Então a gente precisa ir mesmo à Campinas? [risos]}

Aqui vai uma norma acadêmica - uma lição de bons modos, tão ausentes na vida acadêmica de hoje, carregada de oportunismos e alpinismos - que vocês precisam saber. Eu não fui para a Mesa quando convidada pelos organizadores do evento na Assembleia Legislativa de Minas Gerais para discutir sobre o futuro do Brasil, aquilo a qual me referi em uma pergunta anterior. Não fui. A Mesa contava com a participação de Celso Furtado! Falei com o jornalista Mauro Santayana: Primeiro: Como eu vou sentar à Mesa ao lado do meu professor? Segundo: Ele é meu mestre. Quem sou eu? Soube que exibiram durante algum tempo o vídeo, com a gravação da minha fala! Mas eu me neguei estar na Mesa enquanto meu professor falava. Ele chamou e eu não fui. Aí, o Mauro Santayana, que me havia convidado, foi lá: "Adélia, você...". Eu falei: "Eu não vou, Mauro. Eu vou assistir à conferência do professor Furtado daqui onde eu estou. Ele tem tudo o que dizer. Eu não preciso dizer nada". Aí ele voltou para a mesa e referiu minhas palavras ao Professor pude ouvir, pois estava na primeira fila, como convidada que eu também era: "Professor, pode começar, porque a Maria Adélia, que foi sua orientanda, não quer se sentar à mesa ao seu lado". E o que fez o Professor? Chamou-me, ele mesmo, para a mesa! Aí eu disse: "Professor, o senhor vai me desculpar, mas eu vou ouvi-lo daqui e depois eu vou". Reverência ao mestre! Aí ele fez uma magnífica fala, mas não falou como geógrafo, claro! Criei coragem e achei espaço para minha a intervenção geográfica, que precisaria ser impecável. Então, quando ele me convidou novamente para subir até a mesa, eu fui e apresentei minha reflexão. Felizmente, deu tudo certo. Enorme responsabilidade. Depois fomos jantar. Foi a última vez que eu estive com o meu professor e com o jornalista que escreveu aquele livro importante "O Brasil Privatizado" sobre a privataria tucana, o Aloysio Biondi. Fomos eu, o Celso Furtado, o Aloysio Biondi e meu companheiro, que era um velho comunista. Foi um jantar maravilhoso. Logo em seguida, Aloysio Biondi veio a falecer.

Então, é só para dizer que não é brincadeira. Eu sei bem o que eu estou fazendo e qual o meu papel como professora e pesquisadora. Não estou iniciando hoje, não 
sou amadora, não conto essas histórias para me gabar. É porque isso é a minha vida e eu sou educadora!

Gente, é a primeira vez que venho a um congresso nacional, institucional, formal, de Geografia, convidada por colegas meus para proferir uma conferência. Por isso decidi vir! Daí eu pensei: antes de telefonar para o Marcio: "Deve ser uma 'fria'. Acabo de ser reprovada num concurso por lá! Como é que você convida alguém que foi reprovada num concurso, numa universidade federal também mineira, como a sua?" Mas, vejo que me enganei. Estou sendo tratada como muita reverência e respeito por todas e todos os participantes do Geosimpósio.

Professora, sua presença como conferencista deste nosso evento aqui na Unifal-MG é um presente para nós. Para aproveitar o seu conhecimento, queríamos ouvi-la sobre uma questão. Nós temos aqui na nossa região o lago de Furnas, criado por Juscelino Kubitschek. Há 34 cidades no seu entorno. E, constantemente, essa lâmina de água sobe e desce, causando transtornos, impactando a toda a região. Há uma luta perene entre os gestores do lago e outros segmentos sociais dessas cidades.

E não vai acabar nunca se não mudarmos a estratégia e se a dinâmica dos lugares não entrar em ação. A Geografia, com seus conhecimentos, precisa começar também a subsidiar as ações políticas. A Geografia precisa ter institucionalidade como ciência. É só a luta política a partir de baixo, da constituição dos lugares, com o reconhecimento de que o território usado e seu conhecimento é um poderoso ingrediente do resgate da cidadania! Se as pessoas que se sentem prejudicadas tiverem consciência de seus direitos existências ali onde vivem e não apoiar as suas lideranças, quem sabe?... O que acontece nessa psicoesfera ${ }^{15}$ ? Não há um reconhecimento das nossas lideranças políticas sobre essa questão da psicoesfera e da tecnoesfera. Apenas o economicismo e o velho argumento da ciência política vigoram! Minha interpretação é que no âmbito da psicoesfera/tecnoesfera a esquerda (nós todos) e seus líderes fraquejaram, por isso o Bolsonaro está aí! Porque abrimos espaço e continuamos a interpretar equivocadamente a história do Brasil e produzimos equivocadamente a nossa história recente, lá onde vivemos e trabalhamos! A direita e os fascistas souberam definir uma estratégia

\footnotetext{
15 Psicoesfera e tecnoesfera são dois conceitos redutíveis entre si, ferramentas para compreender o espaço geográfico, esse indissociável sistema de objetos (tecnoesfera) e ações (psicoesfera).
} 
contemporânea de luta política. Usando o quê? A instituição de lugar pela internet por meio do WhatsApp. Manipulam e constituem inclusive, criminosamente, os lugares virtuais. Essa é a minha explicação, como geógrafa. Por quê? Porque há uma redutibilidade, diz o Milton, entre tecnoesfera e psicoesfera. O que é a tecnoesfera? É o processo de criação do meio geográfico - técnico-científico informacional, nos termos de Milton Santos - para a reprodução do capital. Sorre e Milton chamam isso de meio técnico. Se não existir o meio técnico, o capital não vinga nesta contemporaneidade. Então eu gostaria, por exemplo, para prosseguir com minhas provocações, compreender, como geógrafa que sou e valendo-me dos conceitos da Geografia que pratico, como um governo de esquerda pode produzir um PAC $^{16}$ viário para a América Latina inteira? Um produto genérico para a Integração da Infraestrutura Regional Sul-Americana, ou simplesmente IIRSA! O que ele está fazendo? Ele está dando de bandeja a fluidez do território. A quem interessa a fluidez do território? Você transporta o quê nas estradas? Pobre? Você transporta o quê? Por que você vai investir nisso? Você vai olhar todo o programa do Mercosul, é o quê? Sistema hidroviário, sistema rodoviário. Está lá no IIRSA! Quem deve promover a integração latino-americana, seu povo ou as empresas multinacionais que, sobretudo, exploram nossas riquezas naturais? Para isso serve a fluidez do território, e desse processo, sabemos, fica para os países muito pouco! A esquerda precisa definir em seus governos outras estratégias e prioridades, que não traiam os pobres. E há como você dar de comer às pessoas fora do capitalismo, sim. Só que você tem de combater aquilo de que o Milton fala, você tem de liquidar com a imagem, com a figura equivocada do consumidor permanente, o consumidor perfeito e o cidadão imperfeito. Isso é uma diretriz política para se elaborar um plano de governo. Se estimula ou não o consumo de massa? A agricultura familiar, por exemplo, é um programa que se desenvolve a favor do cidadão perfeito e contra 0 consumidor mais que perfeito. Isso é uma prática política que se faz "homem a homem", como se diz popularmente, na prática política que precisa nascer da constituição dos lugares, para esclarecer as pessoas sobre nossos problemas. Sistemática e organicamente, como programa partidário, que poderia ser feito mediante uma atividade didático-pedagógica libertária das fundações de que dispõem os partidos. A política agora tem que se fazer assim ou via internet. Só que

\footnotetext{
16 Programa de Aceleração do Crescimento, lançado pelo governo federal brasileiro em 2007, que englobava um conjunto de políticas econômicas.
} 
a internet é empresa, e não é nossa! Mas agora essa é a nossa briga! Não tem como o império americano sobreviver a ela. Ele agora impôs ao governo chinês a taxação para proibir os produtos eletrônicos. Acabou. Então, ele vai fazer os contribuintes americanos pagarem a diferença que ele não está querendo ceder a outra economia? Isso vai sair muito mais caro para o império até aqui hegemônico.

Professora, a gente caminha para o final. A senhora falou muito em política. Existem políticas ou política?

Só existe a Política. Que é uma prática social de pactuação. Isso é a Política. Esse processo de pactuação é um processo de entendimento e de busca do consenso. Só que essa busca do consenso, como o próprio nome indica, precisa envolver a todas e a todos, e não só com uma ação realizada apenas para montar governos e decidir suas estratégias em tempos eleitorais. Vivemos eternamente processos eleitorais, imaginando com isso garantir o futuro e mudar estruturas sociais e fazer a História avançar. Basta constatar o que está acontecendo agora no Brasil! A Política é uma atividade onde tudo e todos precisam estar envolvidos cotidianamente! Caso contrário não inventariemos outras ferramentas políticas para governar que fujam às malditas e frágeis coalisões!

\section{Eu vi uma participação do Milton Santos no Jô Soares em que ele responde} para o Jô Soares isto: Tudo é política.

Tudo é política. Você faz política em casa, com seus filhos, com seu marido, tudo. A política é uma ação que alia perfeitamente razão e emoção para dar certo.

Professora, sentimento, amor, Geografia. Como nós falamos lá no começo desta nossa conversa, hoje é Dia dos Namorados. Comente um pouquinho para a gente sobre isso. Como é fazer ciência com amor, com sentimento e com emoção?

Porque a política é isso. A política é emoção, paixão, amor e racionalidade, tudo junto e misturado. E a racionalidade do mundo se resolverá pela política, não pela economia. A economia é uma ferramenta racional de débito e crédito, de produção e circulação seja lá do que for. Qual é a grande expressão econômica do mundo de hoje? São as Finanças! A produção não o é mais, porque a produção deixou de ser reguladora da existência humana, porque o modo de produção inventou a produção, 
inventou o salário, a mais-valia e a mão de obra. Mas o Marx nos ensinou que não é mão de obra, é força de trabalho. E trabalho é aquilo que agrega valor. Aí tem que ler o Marx para entender isso.

A cada três ou quatro anos havia um colégio mundial de filósofos que se reunia, não sei se ainda se reúne no Collège de France, em Paris, que era o equivalente aos hoje denominados institutos de estudos avançados. Eu me organizava para assistir a essa reunião. E foi lá, no Collège de France, que eu aprendi, na reunião de 1997 ou de 1998, sobre essa nova racionalidade do mundo que é política. Eu tenho as revistas e os documentos lá em casa. Aprendi também que a racionalidade do mundo desde os anos 1970, quando se inventaram as tecnologias da informação, mudou com implicações sérias sobre a vida humana na superfície do planeta. Por quê? Porque o combustível da Política, o fermento da Política, é a informação. Nisso concordo com Raffestin, nosso colega suíço. E a informação é um atributo do sujeito. Eu a tenho e passo para você, mas eu coleto essa informação vinda de outro sujeito ou vinda de um objeto. Isto aqui é um objeto que contém informação. Mas, como papel, aqui sob minha mão, ele se presta a uma funcionalidade, que é a difusão de ideias pela escrita que acolhe. E o que acontece? Você, para resolver um problema de um mundo onde a tecnologia transformou o processo de trabalho - e você tem que estudar o taylorismo, o toyotismo, para saber o que é tudo isso - e tirou a mão humana desse processo. Em vez da mão, a inteligência! $E$ o Marx tem um texto lindo nos ensinando sobre o processo de trabalho e cooperação ${ }^{17}$. É, lá no Neolítico, leitura obrigatória para quem lida com a questão agrária, porque tudo começa quando se inventa o trabalho. O que é o trabalho? O trabalho é a possibilidade que o ser humano teve de transformar a natureza, em seu benefício. Até um certo momento ele regulava o seu trabalho para produzir comida para si. 0 nomadismo existia porque, como não tinham inventado o trabalho, eles só coletavam, nada produziam. Coletavam e não podiam parar, e tinham que caminhar para comer. Eu estudei a fome por isso! Os momentos de fome na história da humanidade, inclusive as práticas alimentares, a antropofagia... tem coisas importantíssimas escritas sobre isso que os pesquisadores da questão agrária certamente conhecem. Então, o que acontece? Essa racionalidade que a economia

17 Karl Marx, O Capital - Crítica da Economia Política, Livro Primeiro: O processo de produção do capital. Quarta Secção: A Produção da Mais-valia Relativa. Décimo primeiro capítulo. Cooperação. 
exige para lidar com o mundo já não se aplica porque ela não resolveu o problema do mundo, foi o que me ensinara os filósofos e epistemólogos lá em Paris. A fome não acabou, o desemprego aumentou e a vida humana não melhorou. Melhorou para pouquíssimos. A produção e a distribuição, chaves do capitalismo, não resolveram por si sós o problema da humanidade. Hoje as estatísticas que permitem construir as pirâmides de renda são assim: tem uns sujeitos na ponta da pirâmide, lá em cima, e uma enorme base aumentando insistentemente, significando a população de baixa renda. Por quê? Há ainda uma racionalidade - isso é que eu aprendi na reunião dos filósofos — a racionalidade econômica, que induz você a pensar sempre economicamente - e você pensa até hoje, para pagar cartão de crédito, para consumir. Você não pensa politicamente! E essa racionalidade não vai mais ajudar a humanidade a evoluir, diziam eles, os filósofos das subáreas da filosofia. O que vai ajudar a humanidade a avançar é a racionalidade política. Que é isso: você se reunir para buscar um consenso, tentar reunir a maioria e definir um projeto comum não apenas político, mas também civilizatório. É essa maioria que os de cima e muitos dos governos não querem ver. Ela está vindo ao mundo agora, essa maioria, como sujeito, organizando-se aqui embaixo, criada por essa dinâmica dos lugares que é o conceito que eu uso e do qual nós, da universidade, não temos noção do que seja - esse mundo dos "homens pobres e lentos" - porque ele se autovigia. Tem uma parte da vigilância a que ele se alia por subordinação — porque os pobres estão sempre sendo marginalizados - ao mundo do crime, ao crime organizado e agora às milícias, que tomou o poder no Brasil. Ou não? Então, eles trabalham e convivem com essa psicoesfera do terror, mas há uns movimentos populares e de massa que trabalham com a psicoesfera da alegria e da felicidade, gente politizada, e o caso exemplar é o do movimento hip-hop. Esse movimento, como sabemos, que nasce nos Estados Unidos para combater a violência que lá ainda é imensa, especialmente com negros e latinos, porque os governos não entendem que as políticas, digo, os pactos para governar não podem mais ser setoriais. Os governos são setoriais por quê? Porque você tem uma secretaria dos transportes, uma secretaria de educação, uma secretaria de economia e planejamento, uma secretaria viária, um ministério da indústria... Por quê? Porque é do interesse hegemônico que seja assim, setorial! Esse tipo de gestão pública setorial facilita os negócios. Dá menos trabalho negociar com um setor do que com a complexidade de um território usado, uma região, um país. Agora, espero que as 
empresas comecem a nos ouvir para criar pactos territoriais. O que é o pacto territorial? Vou mostrar hoje à noite.

Pergunto: O que existe: o centro da cidade lindo, com tudo quanto é serviço, e as periferias sem nada, nem esgoto, nem lixo, nem creche, nem escola, nem centro de saúde, nem telefone, nem rua, quanto mais asfaltada! Por que é assim? Porque a priorização é territorial para os ricos, mas não para os pobres. Há subespaços da cidade onde tem de tudo, e nas periferias... absolutamente nada! É o meio técnico se densificando, densificando... A minha proposta para a esquerda é que ela pense em regular de outra forma essa redutibilidade entre tecnoesfera e psicoesfera, porque essa redutibilidade, para o capitalismo, é criar PACs, é dar fluidez ao território.

Então é um pacto político: assumir o território usado como categoria de análise social, política. "Elaboramos, eu e meus alunos e colegas que amam e estudam São Paulo, um pacto político, de base territorial, para a história da Pauliceia Desvairada resolver o problema da sua periferia." Identificamos os territórios da cidadania e da existência, que são sub-regiões de ação prioritária definidas no território municipal. Discuto a cidade como geógrafa e planejadora territorial, não como economista ou cientista política. Permaneço "no meu quadrado". Hoje cada cidade, cada localidade precisa construir seus pactos territoriais considerando as múltiplas dimensões escalares, geográficas, da dinâmica do mundo. O que é isso? Alfenas é única, única. Espírito Santo do Pinhal, minha terra, é única. Porque a sociedade daqui, os pactos daqui são feitos por quem vive aqui, cotidianamente. E esses pactos mudam a cada instante. Por isso Pierre George, nosso mestre francês dizia que a dimensão do cotidiano entrou na Geografia porque ela, a dimensão cotidiana, muda a paisagem a todo instante. Por isso em meus cursos de planejamento eu ensinava sobre o processo de urbanização - na clandestinidade, na USP [risos], mostrando, pioneiramente, um exercício imaginário de um urbanista suíço que nos mostra isso didaticamente, o material apresentado em pranchas, intitulado The Changing City. Uma beleza. Uso desde os anos 1970 esse precioso material para minhas aulas sobre urbanização.

\section{Qual o nome dele?}

Jorg Muller, o autor. 
Mais alguma coisa que a senhora queria falar, neste final de entrevista, que a gente não perguntou, professora Maria Adélia?

Eu queria dizer que, para mim e para a minha história de vida, esta entrevista tornada depoimento certamente marca, para minha alegria, um momento importantíssimo. Estou numa fase final da vida. Como dizem, tenho mais passado do que futuro. Quem está com oitenta anos... faz tudo para viver mais dez com a cabeça boa. Minha mãe chegou aos 92 com a cabeça boa, e eu tenho parentes que chegaram aos 100. Tenho uma tia que chegou aos 105 anos jogando sinuca, na Itália [risos]. Então eu prometo viver muito ainda, porque sou da velha guarda, comi tomate, arroz, berinjela, feijão, batata, eu comi essas coisas todas sem agrotóxico. Agora, eu não sou ecologista, não acredito nessa besteira metafórica, não acredito na luta setorial, temática. Aprendi com Jean-Paul Sartre e com Ortega y Gasset que a grande luta é estrutural, e sempre se deve sempre levar em consideração as circunstâncias, você tem que ter uma concepção de totalidade sobre o mundo para definir a política. Por não ter essa concepção de totalidade/mundo é que toda hora se divulgam, inclusive pela própria esquerda, conceitos que não incorporam a totalidade, deformando cada vez mais os processos de lutas e atrasando-os. Um deles foi, por exemplo, o conceito de multissetorialidade. Isso, no planejamento, vigorou e vigora ainda hoje, infelizmente. Cansei de fazer reuniões juntando pessoas, mas sem ninguém para ter autoridade para tirar um resultado único dessa multidisciplinaridade no planejamento. Hoje percebo que era óbvio: cada um voltava para a sua secretaria e continuava a pensar e a fazer tudo como sempre no seu setor, sem ideia de uma totalidade que a multissetorialidade não alcança. Nunca conseguimos emplacar as políticas territoriais que formulávamos para São Paulo, para o país... Tudo continua a ser pensado e resolvido setorialmente, e não territorialmente. Tudo permanece igual, inclusive as lutas sociais, que lamentavelmente ainda são feitas sem as políticas territoriais, indispensáveis para o processo de pactuação ao qual me venho referindo insistentemente nos últimos anos.

No planejamento público juntávamos todo mundo - o representante da educação, o da saúde - para trabalharmos juntos. Chamávamos isso de trabalho multissetorial, e, aliás, ainda hoje ouço dizer que ele é feito. Santa ingenuidade, santo desconhecimento! Mas, sabe por que não dá para trabalhar? Porque cada setor hegemônico atende, de maneira subjacente, malgrado a boa vontade dos técnicos 
do governo, a um interesse que não tem representação popular, quero dizer, não atende ao interesse popular, mas apenas ao interesse e à representação de empresas. Em regra geral, governar é possibilitar negócios, e lamentavelmente, junto com a educação e a saúde, os transportes, o saneamento e por aí vai.

Então você trava a luta pela habitação, e eu lamento que os sem-teto, por exemplo, que o Guilherme Boulos lidera de forma brilhante, lutem, lutem, mas estando sempre sob ameaça. Por isso eu digo que a estratégia política setorial está errada, porque Ihe falta a explicitação do projeto global. Na existência, um setor apenas não resolve problema algum: quem precisa de casa precisa de emprego, escola, saúde, comida, lazer, cultura (criar ou assimilar) etc. etc. Getúlio Vargas teve uma preocupação central com a questão habitacional. Quando ele voltou, democraticamente eleito, depois do Estado Novo, fez um trabalho magnífico, o da Fundação da Casa Popular, muito melhor do que se fez posteriormente, e mais recentemente, tragicamente, com o engodo do $\mathrm{BNH}$, com a criação de seus programas especificamente para as classes médias. Desculpem-me, Minha Casa, Minha Vida não é um programa de massa. Mais uma vez, os pobres ficam ao Deus-dará, sem serem atendidos em nada! Nenhuma proposta de desfavelamento, ou coisa que o valha. E não é porque não tenham sido construídos milhões de habitações. É que o problema não consiste apenas em construir habitações... Isso não terminará nunca. Sejamos honestos! As favelas e os pobres só fazem aumentar o seu contingente. O problema pelo qual temos de brigar, e muito, não é setorial. É estrutural, portanto, difícil, complexo, de largo prazo, e quem lida com isso é a política, e os pactos territoriais, como princípio de método político. Vejam, não conseguimos ainda elaborar um projeto nacional para o Brasil. Ele ainda é econômico e financeiro. Logo é empresarial, e não nacional, da nação. O processo de empobrecimento das pessoas, que esse modo de ser das lutas políticas implica, é crescente e não vigora só na habitação. Tanto é - fiz essa experiência na favela da USP - que nas situações extremas a primeira coisa que o cara vende para comer e cuidar da família, ou até mesmo para buscar e mudar de status social, inclusive pagar dívidas, é a venda de sua casa ou de seu barraco. Ele não tem mais nada de valor para perder, só the restando, para sobreviver, vender a sua miséria. Muitas questões a serem discutidas neste imenso mundo da práxis!

\section{Ele negocia. Todo mundo negocia.}


A favela São Remo, por exemplo, que estudamos a fundo quando fui prefeita da USP, onde construí uma casa de terra na expectativa de que o governo Montoro reproduzisse essa experiência em pequenas comunidades rurais. Você gastava na época cerca de quatro a doze mil reais e tinha uma casa de qualidade, com certificados do IPT (Instituto de Pesquisas Tecnológicas) de São Paulo e tudo o mais. Ganhamos, na época, um prêmio da UNESCO com essa casa de terra feita com meus colegas da Engenharia e da Arquitetura, que se dispunham a pensar a casa de outro modo, com outra tecnologia. Aliás, esse tema era muito discutido nos anos 1970, 1980. Era outra a realidade na lida com as técnicas, bem diferente do que aconteceu depois, já no final século XX e ainda agora, no XXI. Havia muitas alternativas de casas com processos construtivos baratos e factíveis - em Pernambuco, por exemplo. Mas essa experiência da USP foi bastante pioneira e se espalhou, dando ânimo para se pensar em novas propostas em prol do Brasil inteiro. Porque a USP é difusora de ideias.

Então eu queria agradecer. Acho que é uma alegria eu poder morrer tendo tido, pelo menos uma vez na vida, o reconhecimento dos meus colegas professores pelo meu trabalho - institucionalmente.

\section{Nós é que agradecemos.}

Isso é emoção. Isso é viver.

Professora, antes de finalizar, gostaríamos de pedir uma mensagem sua, rápida, para os estudantes.

Olha, eu devo aos estudantes do Brasil a minha carreira. Se não fossem eles, eu teria desistido de ser geógrafa há muito tempo. Quando voltei para o departamento de Geografia da USP, fiquei uns seis anos sem nenhum aluno porque ninguém me procurava, nem para fazer uma iniciação científica... Corriam boatos políticos, havia patrulhas ideológicas equivocadas. O segundo livro, que pretendo lançar brevemente, é dedicado ao primeiro aluno que foi me procurar e que, lamentavelmente, morreu num acidente de ônibus ainda como meu aluno. Ele se chamava Dalterli Rubens Castrisana. Sou muito grata a esse menino que virou anjo... E era comunista! Foi ele quem me resgatou, e a partir daí eu comecei a ter alunos no departamento de Geografia quando consegui voltar para lá em 1985, por aí... 
Obrigado, professora.

\section{Notas de Autor}

\section{CONTRIBUIÇÃO DE AUTORIA}

Gil Carlos Silveira Porto - Concepção. Realização da Entrevista. Edição. Revisão da versão final do texto. Márcio Abondanza Vitiello - Realização da Entrevista. Edição. Revisão da versão final do texto.

\section{FINANCIAMENTO}

Não se aplica.

\section{CONSENTIMENTO DE USO DE IMAGEM}

Não se aplica.

APROVAÇÃO DE COMITÊ DE ÉTICA EM PESQUISA

Não se aplica.

\section{CONFLITO DE INTERESSES}

Não se aplica.

\section{LICENÇA DE USO}

Este artigo está licenciado sob a Licença Creative Commons CC-BY-NC. Com essa licença você pode compartilhar, adaptar, criar para qualquer fim, sem uso comercial e desde que atribua a autoria da obra.

\section{HISTÓRICO}

Recebido em: 30-08-2020

Aprovado em: 15-09-2020 